\title{
КИРджА Н.О.
}

https://orcid.org/0000-0001-9856-774X

Середземноморський Університет (Анталья, Туреччина)

violastar07@hotmail.com

\section{ЄВРОПЕЙСЬКІ МУЗИЧНІ ТРАДИЦЇ̈ В АЛЬТОВИХ ТВОРАХ ГЕННАДІЯ ЛЯШЕНКА}

Розглянуто відомі твори композитора за участю альта - цикл для альта з фортепіано «Прелюдія, Арієта і Танець», «Соn amore» для альта 3 камерним оркестром, «Технема № 2» для флейти, альта і арфи та Концерт для альта з оркестром, що є яскравим втіленням авторського «чуття» специфіки інструмента. Вказано на експресивно-ліричний характер фактури творів, наявні зв'язки з колористичними традиціями імпресіоністів. 3'ясовано, що у творах Г. Ляшенка виявляється авторське особливе ставлення до тембрових і технічних можливостей, а також до колоритного звучання цього інструменту.

Ключові слова: альт, репертуар для альта, колористика, українська інструментальна музика.

Постановка проблеми і аналіз останніх досліджень. Становлення альтового репертуару у XX столітті пов'язане з особливостями розвитку національних композиторських шкіл, зокрема, тих, у яких камерне музикування є глибинною традицією, докорінно пов'язаною з історією європейської музики. Цим же шляхом розвивається і українська альтова школа.

Тема традицій та новаторства камерної музики в Україні, їі становлення i розвитку є однією 3 найбільш плідних сфер музичних досліджень. Це пояснюється високою духовністю камерної музики, іiі невичерпним потенціалом ідей, обмін якими втілюється у живому концертному спілкуванні невеликих музичних складів. Спостережено, що «камерне музикування як форма творчого спілкування найдосконаліше втілює процес становлення художньої особистості» $[2,4]$; і дійсно, сфера камерної музики $\epsilon$ найбільш широким полем використання експериментальних технологій, нових концепцій та засобів. Камерна музика в Україні, корені якої - в європейському мистецтві, є відносно молодою, адже до 1920-х років жанр камерно-інструментального ансамблю в Україні тільки зароджувався. I тому, на думку I. Боровик, «тим дивовижнішим $\epsilon$ той стрімкий шлях становлення <...> який він пройшов від ранніх опусів М. Лисенка й С. Людкевича до грандіозних композицій Б. Лятошинського...» [2, 4].

Твори для альта Геннадія Ляшенка, одного з найяскравіших представників

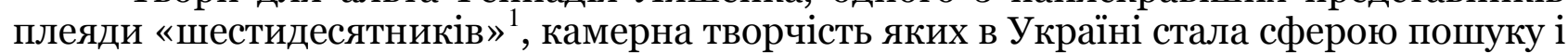
новаторства, розхитування стереотипів сприйняття та втілення нових звукових ідей, займають певне місце в історії розвитку української камерної музики. Як характеризує творчість «шестидесятників» І. Боровик, в центрі композиторської уваги постає тема особистості з усіма її суперечностями. «Твори цього періоду визначені неординарністю організації звучащої матерії в часі і просторі; новими типами тематизму, їх

${ }^{1}$ До камерних творів цього періоду відносяться опуси В. Бібіка, В. Годзяцького, Л. Грабовського, Л. Дичко, Ю. Іщенка, В. Сильвестрова, Є. Станковича та ін. 
афористичною місткістю; підвищеною експресією мовлення; високим рівнем напруження гостродисонуючої інтерваліки; сміливістю та виразністю агогіки, проникнення в музичну інтонацію мовного начала; складністю інтонаційної сфери в каденціях; живим ритмом мішаних тембрів та багатоманітністю сполучень чіткої метроритмічної організації з перемінними та нефіксованими метрами; множинністю композиційних рішень; розширенням звучащого простору за рахунок включення крайніх регістрів та найвищим динамічним напруженням у зв'язку з використанням усієї шкали динаміки, що передбачає високе мистецтво нюансу; збагачення художніх засобів вираження новими способами звуковидобування, звуковим живописом алеаторики та непередбачуваними сонорними ефектами [2, 5].

3 часів початку діяльності плеяди композиторів-шестидесятників в Україні змінилося багато поколінь музикантів, що присвятили свою творчість саме сфері розвитку камерної музики. Проте, актуальність напрямків розвитку жанрів камерного ансамблю залишається незмінною: камерна музика в Україні є надзвичайно мобільною i артистичною сферою особистісного вираження, чутливою до змін естетичних і музичних напрямків, до новацій - художніх та технологічних.

Метою дослідження є ознайомлення широкого музичного загалу, спеціалістів-викладачів, виконавців з репертуаром, унікальним у багатьох сенсах: смислова насиченість, національна визначеність, впізнавана авторська мова, вишуканість деталей, які зробили твори Г. Ляшенка частиною традицій європейської альтової музики і представляють українську альтову школу в багатьох країнах світу.

Викладення основного матеріалу. Звертаючись до альтової творчості Геннадія Ляшенка, композиторська практика якого розпочалася в шестидесяті роки минулого століття, з першого погляду визначається як найважливіша характеристика його творів - їх європейська приналежність. Дослідниками відзначається, зокрема, що «створивши власну оригінальну музичну мову, яка в свою чергу вплинула на кристалізацію індивідуального й неповторного композиторського стилю, він здійснив інтеграцію в загальноєвропейський музичний контекст і посів чільне місце як один з найяскравіших вітчизняних митців XX століття» $[4,13]$.

Твори для альта мають особливе значення в доробку композитора: вони біографічні. Дружина композитора Ж. Ляшенко є за фахом альтисткою; вона більше ніж півстоліття працювала на кафедрі струнно-смичкових інструментів Національної музичної академії України ім. П.І.Чайковського, викладаючи у квартетному клаci. Їй присвячено один з ранніх циклів для альта та фортепіано, в сюїтному жанрі Прелюдія, Арієта і Танець (1971); вона ж була першою виконавицею цього твору.

За згадками колег, цей твір часто виконувався на іспитах кафедри камерного ансамблю Київської консерваторії, був у репертуарі видатного викладача кафедри струнно-смичкових А. Венжеги, входив до числа конкурсних обов'язкових творів, створених українськими композиторами. Сюїта створена молодим композитором, і в ній ще присутні різні стилістичні впливи.

Так, наприклад, перша (сольна) частина «Прелюдія» нагадує відоме бахівське «Адажіо» 3 сольної скрипкової Партити; відсутність супроводу дозволяє слухачеві зосередитись на буквально «скульптурному» творенні ідеї - засобами «чистого» тембру. Драматизм образу посилює лірико-драматична «Арієта»; висхідні та низхідні рухи хроматичних гармоній створюють високу напругу. Партія альта виписана як контрапунктуючий голос - самостійний, проте не головуючий. Поліфонічна течія фактури, «кризові» постромантичні гармонії, нерозв’язаність запитань - ось такі характеристики цієї частини. Натомість, наступний «Танок» - типовий жанровий фінал. В гармонічній мові та фактурі тут учуваються впливи С. Прокоф'єва, зокрема, 
його фортепіанного циклу «Сарказми». Присутність гуморескового колориту врівноважує образну структуру циклу у фінальному віртуозному скерцо, характерному також для фіналів багатьох творів композиторів-романтиків.

Уже в цьому одному з перших камерних циклів композитора спостерігається така його якість, як вільне трактування жанрових типів; своєрідність сюжетних перипетій та прихована програмність, що дає можливість виконавцю індивідуально «читати» складні музичні тексти цього автора [5].

Так, одночастинна концертна композиція Г. Ляшенка «Con amore» для альта та камерного оркестру ${ }^{1}$ (2003) являє собою приклад опусу в жанрі «музичний дарунок». Перший виконавець цього твору - викладач кафедри струнно-смичкових інструментів НМАУ ім. П.І. Чайковського Андрій Тучапець.

Твір являє собою оригінальний приклад «реставрації» вишуканого європейського музичного жанру: про його популярність в європейській камерній (салонній) музиці свідчать опуси різних стильових напрямків, як, наприклад, 10 канонів Й.С. Баха 3 клавірного циклу «Музичний дарунок» (рос. «Музыкальное приношение»); як різновид музичного дарунка виникає жанр багателів (Ф. Куперен, Л. Бетховен); доречно згадати також жанрово-стильову модель, що виникла як прототип програмної сюїти-hommage та ін. В українській музиці до жанру «музичного дарунка» належать, наприклад, всесвітньо відомі модифікації українського твору «Щедрик» (автор оригіналу - М. Леонтович) - анонімні та авторські, які внаслідок значного поширення отримали умовну назву «музичний дарунок світу» («музична колядка дзвонів»). У цьому ж жанрі написано Концерт для симфонічного оркестру I. Карабиця «Музичний дарунок Києву» та деякі інші камерні твори без жанрового визначення, що є прикладами ретроспективних тенденцій у творчій практиці більшості національних шкіл, і які представляють індивідуально-авторські моделі реставрації, осучаснення методу так званих «варіацій на жанр».

У цьому одночастинному творі поєднання наскрізного типу розвитку з фрагментарною багаточастинністю утворює оригінальну жанрову модель, яка розгортається у віршовому ритмі елегії (як аналогія виникає паралель 3 популярною альтовою «Елегією» А. В’єтана, п’єсою «поетичного» типу жанру). Проте, елегійність має «приховані» ресурси драматизму; починається п’єса з елегантного коливання оркестрової фактури, на якому вимальовується яскрава широкоінтервальна тема-звертання. Всі тематичні елементи проростають з одного мелодико-гармонічного зерна; відразу з'являється i суперечний образ (т. 10) - синкопована гостроритмічна розімкнута висхідна інтонація. Септакордові послідовності, що замикають епізод, створюють враження абсолютної гармонії, на досягнення якої спрямовані всі метаморфози тексту.

Інтенсивне мелодичне обігрування у розробковому епізоді, прийоми поліфонічного обернення тем, імітації, зміни метричних та неметричних епізодів, імпровізаційність впливають на рефлексивний характер авторського тексту; моментальність кульмінаційних підйомів вибудовує легку і струнку конструкцію, в якій переходи на інші рівні відбуваються непомітно, без участі зв'язуючих побудов. Регістрова колоритність, гармонічна і метрична щільність фактури, крещендуюча динаміка каденційного розділу (т. 60), відтіняє віртуозну сольну мелодекламацію і призводить до ліричної кульмінації (епізод Piu mosso).

\footnotetext{
${ }^{1}$ Існує також версія для кларнету та фортепіано.
} 
3 епізоду Тетро 1, з репризним проведенням основної теми, повертається врівноваженість патетично-ліричного настрою. В цьому лаконічному творі, який є ніби етичним маніфестом автора, виявляється його глибоке відчуття лірично-драматичної тембрової природи альта, її сакрального змісту.

Іншим зразком ансамблевого твору за участю альта є Технема № 2 для флейти, арфи та альта (2012). Твір декоративно-колористичного напрямку є продовженням традицій тріо-композицій, що ведуть свій родовід від класичних (Л. Бетховен), романтичних (Й. Брамс, П. Чайковський), імпресіоністичних (К. Дебюссі, М. Равель) - до численних творів сучасників, у складі яких варіюються різноманітні поєднання струнно-щипкової основи (альт, арфа) та духових.

«Технема № 2»- це частина п’ятичастинного циклу «технем» для різних складів інструментів; оригінальний жанр, створений Г. Ляшенком, вірогідно, за аналогіями 3 давньогрецьким мистецтвом сольного та камерного музикування. Це одночастинний твір; проте в ньому яскраво вирізняється декілька драматургічнокомпозиційних фаз. Оригінальність його композиції в тому, що основна тема з'являється в кінці, у третій чверті композиції (5 т. до ц. 10), являючись фактично підсумком попереднього. Разом з їі проведенням у формі хоралу, в супроводжуючих голосах виявляються елементи репризи - нисхідні та висхідні пасажі, ладово окреслені (композитор використовує як ладову модель гемітонні лади), з яких починався перший фрагмент твору (Improvizato). Колоритні пасажі цього фрагменту доповнюють одне одного різноманітними відтінками, що нагадує імпресіоністичну палітру. Друга тема експозиції - тріольне остинато sul ponticello у альта.

Разом $з$ флейтовим голосом (з ц. 4) створюється щільний фактурний шар, який обігруючись різними тембровими штрихами - репліками солістів - призводить до першої кульмінаційної зони та бурхливого спаду (перед ц. 7). Він має розробковий характер; поліфонічне дублювання голосами теми у збільшенні $\epsilon$ основою, яка характеризує варіативний метод цього фрагменту. Цифра 7 - новий тематичний епізод у середині (розробці). Монологічно-діалогічний тип викладу характеризує цю тему як тему широкого дихання (нескінчена мелодія); проте, з ц. 9 вже з'являються репризні елементи та тематичні «передумови» фіналу-хоральні елементи.

Власне, тема-хорал є основним образом цього твору, експресивно-драматичним підсумком романтичної циклічної форми, що в даному випадку має одночастинне втілення.

Концерт для альта з оркестром, написаний у 2006 році; він присвячений першому виконавцю, професору кафедри струнно-смичкових інструментів Дмитру Гаврильцю. Концерт має непрямі аналогії з альтовими концертними творами, зокрема М. Регера, П. Хіндеміта та Б. Бартока. Надзвичайно цілісна одночастинна композиція являє собою приклад монологічного типу творів з наскрізним типом розвитку. Цим самим жанр цього концерту виявляє подібність до поеми; поемність вбачається у поетиці головної теми, у чергуванні елегійних епізодів з динамічно-рухливими; у імпресіоністичних тонах інструментального супроводу, де ефект музичної «світлотіні» виявляється завдяки мікро-реплікам солюючих контрастних сольних тембрів; у поліфонічній природі теми солюючого альта.

Ознаки концертності - у контрастуванні двох образних сфер: висхідних або ламаних пасажів альта і оркестрового супроводу та медитативно-споглядального образу теми. Практично одна тема є в основі усього твору: цим пояснюється інтонаційна цілісність фактури та його драматургічна «компактність». Тема широкого ін- 
тервального складу,що дає багаті можливості для її варіаційної обробки; мелодика їі обмежена певним ладовим модусом.

Як часто трапляється в альтових творах Г. Ляшенка, концерт розпочинається вступним епізодом Improvizato (до ц. 3). Тут вже добре прослуховується мелодична основа теми. Чергування швидкоплинних алеаторичних епізодів (перші три початкові антифонні репліки «оркестр-соліст») та короткого ліричного монологу в епізоді Andantino (де вперше експонуються елементи теми) продовжують: а) зв'язуючий контрастний сонорний епізод; б) другий тематичний фрагмент (ц. 3); в) невелика варіаційно-розробкова частина, побудована на основах інтонаційного матеріалу (цц. 4-5); г) підсумовуючий кульмінаційний епізод оркестру Piu mosso; - так виглядає експозиційна частина концерту.

Одною з характерних ознак тематичного матеріалу є його розробковість. Взагалі, варіаційність та розробковість як принцип втілення моно-ідеї, притаманна авторському стилю Г. Ляшенка. Вона є засобом вираження експресії, динамічної побудови кульмінаційних зон, i, водночас, обігрує принцип контрастності, властивий концертній музиці. Саме в розробці та їі середній частині ${ }^{1}$ у вищезазначених альтових творах Ляшенка часто відбувається виклад основної теми.

В альтовому концерті розробкова частина починається з контрастного темпу Allegro (ц. 6) туттійним звучанням соліста та оркестру, тобто контрастним типом фактури. Головна тема, що звучить в епізоді (ц. 8) викладена у поліфонічному супроводі оркестру (використовується принцип канону); iï мотивний розвиток і заключна частина, що повертаються до характерного руху на початку розробкового епізоду, підкреслюють певну циклічність розробкових фрагментів. Важливими драматургічними віхами цього твору виявляються каденція оркестру (епізод ц. 14) та сольна каденція (ц. 18), що призводить до нової розробкової хвилі на матеріалі вступу, другої (акордової) каденції соліста (ц. 21) та репризи (ц. 23). Власне реприза має такі фази: а) поліфонічний виклад головної теми (на тлі рухливого остинато в оркестрі, заснованого також на інтонаціях головної теми); б) проведення теми в оркестрі (ц. 26); в) реприза вступу (ц. 27) та г) кода, в якій головна тема перетворюється на колискову (від ц. 28).

Таким чином, конспективно аналізуючи етапи становлення авторської ідеї, приходимо до висновку про цілісне розгортання усіх елементів музичного тексту - в оригінальну моноциклічну форму, що об'єднує ознаки одночастинності та дзеркальної репризної тричастинності. Лірико-драматичний зміст твору виявляється як у масштабі інтонаційно-тематичному, так і в драматургічно-композиційному.

Короткий огляд творів Геннадія Ляшенка для альта дозволяє зробити висновки про їх непересічне значення в історії української камерної музики; альтовий доробок композитора є вагомим внеском у скарбницю європейської культури камерного музикування. Розширюючи традиційне розуміння технічних і колористичних можливостей інструменту, композитор вибудовує нову концепцію образного змісту альтової музики, як персонального «авторського меседжу», що вміщує глибокі філософські ідеї європейської культури, насичені художніми сенсами українського мистецтва та фольклорними алюзіями.

Практичне значення дослідження. Виконання подібного роду творів потребує оволодіння специфікою європейського «камерного стилю» звуковидобу-

${ }^{1}$ Епізод у розробці загалом є характерним для тричастинної або одночастинної сонатної форми творів європейських композиторів-романтиків. 
вання та характеру штрихів, вишуканості й тонкості артикуляції, різноманіття звукової та тембрової палітри. Сучасні камерні ансамблі, що вийшли за межі салонного масштабу музикування, потребують досягнення «колективної індивідуальності» (термін Р. Гураля), не тільки шляхом напрацювання ритмічної та інтонаційної досконалості звучання, але й, насамперед, усвідомлюючи важливість обміну індивідуальними сенсами - у масштабі загального. Власне, цією ідеєю керується розвиток як світової, так і європейської культури.

\section{СПИСОК ВИКОРИСТАНИХ ЛІТЕРАТУРИ І ДЖЕРЕЛ}

1. Боровик І. Твори для тріо. Музика, 1984. № 4 (липень-серпень). С. 21.

2. Боровик I. Український камерно-інструментальний ансамбль. Київ : Центрмузінформ, 1997. $118 \mathrm{c}$.

3. Садова Л. Стильові особливості ансамблевих творів Г. Ляшенка // Українська фортепіанна музика та виконавство: стильові особливості, зв'язки з музичною культурою Західної Європи : матеріали III наук.-практ. конф. Асоціації піаністів-педагогів України. Львів, 1994. C. 75-76.

4. Сачева T. Сторінками музики Геннадія Ляшенка. URL: http://www.umoloda.kiev.ua/number/1315/164/46426/ (дата звернення: 15.06.2018)

5. Шурова Н. Пошуки жанрового синтезу // Культура і життя. 1984. № 17 С. 10.

\section{REFERENCES:}

1. Borovyk, I. (1984), "Works for a Trio", Muzyka [Music], vol. 4, p. 21. [in Ukrainian].

2. Borovyk, I. (1997), Ukrainian Chamber Instrumental Ensemble, Tsentrmusinform, Kyiv, 118 p. [in Ukrainian].

3. Sadova, L. (1994), Stylish features chamber works by Hennady Liashenko, Ukrajinsjka fortepianna muzyka ta vykonavstvo: styljovi osoblyvosti, zv'jazky z muzychnoju kuljturoju Zakhidnoji Jevropy [Ukrainian Piano Music and Performing: Stylish Features, Communications with Music Culture of Western Europe] : Materials of the III scientific-practical conference of the Association of pianists-teachers of Ukraine. Lviv, 75-76 p. [in Ukrainian].

4. Sacheva, T. (2008), "Pages of music by Hennady Liashenko", available at: http://www.umoloda.kiev.ua/number/1315/164/46426/ (accessed 15 June 2018) [in Ukrainian].

5. Shurova, N. (1984), "Searches of Genre Synthesis", Kuljtura i zhyttja [Culture and Life], vol. 17 (22.04.1984) [in Ukrainian].

Стаття надійшла до редакиії 20.06.2018 р.

\section{NATALYA KYRDZA}

https://orcid.org/0000-0001-9856-774X

Mediterranean University (Antalya, Turkey);

violastar07@hotmail.com

\section{European musical traditions in the pieces for viola by Hennady Liashenko}

Relevans of the study. The developing of viola's repertoire in XX century has nearest connections with the rebuilding conditions of national instrumental schools: especially, of those ones, where chamber musical art has the mainly way. Connections 
between national school and European art in Ukrainian music for viola are deep and widely demonstrated. H. Liashenko's creation for viola and piano, viola and Chamber orchestra, are very popular among the performers. The rich associations, new senses or new meanings about viola timbres specifies in his works are crossed with the achievements of great European compositions for viola (Brahms, Reger, Hindemith, Bartok, impressionist style from Debussy).

We can seeing that in Liashenko's early work for viola and piano "Prelude, Arietta and Dance" (1971) and in his next works - such as "Con amore" (composer noted its specifically genre as "musical gift") for viola and chamber orchestra (2003), in his Viola Concert with chamber orchestra (2006) and also in his next "Technema number 2" for viola, flute and harp (2012). Expressions and lyrics in the same time, dramatic waves and coloristic ranges are for him the reasons to discover viola's timbre and technical possibilities for its exactly impressions.

Main objective of the study in the area of raising the borders of viola's repertoire, because Liashenko's works now are really the part of European music for viola and they represent Ukrainian viola music in the whole of the world. From Liashenko's style unique features are strong feelings, deep senses, nationally quality, personality and individual musical language, - and they all are important to reconstruct his composer method. Methodology. The main methodology in this studying is the comparative analyses, which used in the historical and theoretical recourses. Results and conclusions. The works for viola by Hennady Liashenko are the important ones in the sense of renews conception of European traditions. In our meanings they are such an author "messages" which contain deep philosophical ideas of European culture, nature from Ukrainian art, folk impress. Practical significance. The pieces for viola by $\mathrm{H}$. Liashenko in our means is the necessary adding to viola's repertoire for professional studying. These ones are musical examples, which step by step open specifies of Ukrainian viola art in its Europeaning context.

Keywords: viola, repertoire for viola, colorizing, expressivity, European traditions, Ukrainian instrumental music.

\section{КЫРДЖА Н.О.}

https://orcid.org/0000-0001-9856-774X

Средиземноморский Университет (Анталья, Турция);

violastar07@ hotmail.com

\section{Европейские музыкальные традициив альтовых сочине- ниях Геннадия Ляшенко}

Актуальность исследования. Становление альтового репертуара в XX веке тесно связано с особенностями развития национальных композиторских школ, в частности, тех, где камерное музицирование является глубокой традицией, корни которой - в исторической связи с европейской музыкой. Такой же путь можно проследить и в украинской музыке, написанной для альта. Камерное творчество Геннадия Ляшенко имеет значительную востребованость среди исполнителей; его альтовые сочинения представляют глубокий интерес, - как в плане постижения инструментальной природы альта, так и в смысле расширения образной сферы украинской ка- 
мерной музыки индивидуальными смыслами, ассоциативными гранями европейского музыкального искусства.

Как в раннем сочинении для альта с фортепиано «Прелюдия, Ариетта и Танец» (1971), так и в последующих произведениях - «Con amore» (жанр которого обозначен как «музыкальное приношение») для альта с камерным оркестром (2003), в Концерте для альта с оркестром (2006), а также, в «Технеме № 2» для флейты, альта и арфы (2012), ярким выражением авторского слышания специфики инструмента можно назвать экспрессивно-лирическое начало, которое характерно для ряда альтовых сочинений конца XIX - середины XX века (Й. Брамс, П. Хиндемит, М. Регер, Б. Барток); в то же время, в ансамблевых сочинениях прослеживаются связи с колористическими традициями импрессионистов (К. Дебюсси). В сочинениях Г. Ляшенко проявляется активное авторское отношение к тембровым и техническим возможностям инструмента, его индивидуальное слышание красочности альта.

Целью статьи является ознакомление широкого круга специалистов в области альтовой педагогики и альтового исполнительства с репертуаром, который уникален во многих отношениях - смысловой насыщенности, национальной определенности, индивидуального авторского языка; сочинения для альта Г. Ляшенко уже стали частью традиции европейской альтовой музыки и представляют украинскую альтовую музыку во многих странах мира. Методы исследования. Ведущим в работе является метод сравнительного анализа, применяемый в историкотеоретическом ракурсе.

Выводы. Сочинения для альта Геннадия Ляшенко представляют значительный вклад в историю развития европейского альтового исполнительского искусства. Расширяя традиционное понимание технических и колористических возможностей инструмента, композитор «выстраивает» новую концепцию образного содержания альтовой музыки, как индивидуального «авторского» послания, содержащего глубокие философские идеи европейской культуры, насыщенные художественными образами украинского искусства, фольклорными аллюзиями. Практическое значение. Сочинения для альта Г. Ляшенко, на наш взгляд, необходимо включить в число обязательных произведений профессионального обучения альтиста, как образцы, последовательно представляющие украинское альтовое искусство в европейском контексте.

Ключевые слова: альт, репертуар для альта, колористика, экспрессивность, европейские традиции, украинская инструментальная музыка. 